for the amendment of the land laws. Among the reforms it is intended to propose is the reintroduction of the system of tribal tenure. It is understood that this proposal has the approval of the Indian Office. Suggestions are also to be considered for the establish. ment of a system of credit for the Indians in order to enable them to equip and stock their farms, as they are not otherwise in a position to work any land which may be assigned to them. It is certainly desirable that something should be done to establish on an economic basis the half-detribalised Indians who at present are largely parasitic on the fringes of white communities. The passing of a revised landlaw which would restore the Indian to the land without the power of alienation would probably prove a substantial advance in that direction.

\section{Grading of Empire Hardwoods}

A sMall brochure has been prepared by the Imperial Institute Advisory Committee on Timbers entitled "Grading Rules and Standard Sizes for Empire Hardwoods" (Imperial Institute, South Kensington, Oct. 1933). The Sub-Committeo, appointed by the Advisory Committee, decided that these inquiries should be confined to overseas Empire square-edged hardwoods. The grading rules and memorandum on sizes recommended by it will be subject to amendment from time to time, as further experience is gained. The grading rules for Empire hardwoods (square-edged) intended for shipment to the United Kingdom are considered under: A. Hardwoods from Countries other than Canada and New Zealand, I Standard Grades. II Wormy Grades. III Grades for shorts, squares, strips, quarter-sawn stock. B. Canadian Hardwoods. C. New Zealand Hardwoods ; and appendixes. This piece of work was overdue and should prove of great value to all concerned in this matter of hardwood imports. The danger of laying down hard and fast grading rules for any particular item of imports may result, however, in great waste at the source of origin-a waste which has to be seen on the spot to be fully realised. For example, under "Squares" it is stated, "First Quality or Prime Squares must be free from all defects, except that, when squares are sold specifically for turning, slight defects on one or more corners which will turn off will be admitted". In the case of mahogany, to obtain the flawless squares, sections of logs of 2-4 ft. will be cut off and left to waste in the forest owing to some small flaw which the manager on the spot will not risk sending home since he will be censured by the management. The latter will not have this type of material sent home since they know it will be objected to by the buyers. Is it necessary to waste annually thousands of cubic feet of so magnificent a timber as mahogany because the specification of import laid down by the purchaser approaches an ideal ?

\section{Wireless Communication at Mount Everest}

A paper entitled "Wireless Communications with the Mount Everest Expedition, 1933", read before the Royal Society of Arts by Mr. D. S. Richards, has now been published (J. Roy. Soc. Arts, May 11). The plans provided for the installation of a main fixed station at Darjeeling, the starting point of the expedition, and two mobile transmitting and receiving stations to be erected at the Base Camp and Camp III at altitudes of $16,800 \mathrm{ft}$. and $21,000 \mathrm{ft}$. respectively. The distance from Darjeeling to the Base Camp was about 111 miles, with a further 10 miles to Camp III, from which a telephone line was to be laid to Camp IV about $1 \frac{1}{2}$ miles distant and at a height of $22,800 \mathrm{ft}$. Communication was carried out by telephony when possible, with recourse to Morse telegraphy when conditions were less favourable. Wave-lengths in the region 40-60 metres were found to be the most successful, and the best time for communication was in the early morning when fading and interference from atmospherics were reduced to a minimum. On the whole, the wireless equipment worked satisfactorily, and the service provided was of great value to the climbers. Weather reports were delivered to Camp IV within an hour or two of their being originated in Calcutta. Radiotelephony proved a great success on occasions, notably when H.E. the Governor of Bengal spoke to some members of the expedition from Government House, Darjeeling, and also when the Civil Surgeon in Darjeeling was consulted about some medical cases. Dr. Greene also carried out a diagnosis by radio between Base Camp and Camp III when there was no doctor in the latter Camp. Not least among the advantages provided was that of the reception at Base Camp of broadcasting programmes and news bulletins.

\section{Road Construction in New Germany}

If we leave the United States out of account, it is at first sight curious that countries overburdened with financial liabilities take the leading part in promoting road construction. During a period of great prosperity, the United States built a gigantic network of highways. Yet when unemployment increased, further energetic steps were taken to increase the road work being done. During the former period, maximum use was made of machinery, but now the tendency is to employ manual labour as much as possible. In Roads and Road Construction of April, there is an interesting paper by Prof. K. Kruger, of the Technical High School, Charlottenburg, describing the latest German autobahn (superhighway) scheme. At the motor exhibition in March at Berlin, Herr Hitler urged the encouragement of motor-vehicle traffic as this would provide work for hundreds of thousands of men. The autobahn project has been fostered, and the construction of powerful high-speed vehicles-almost semi-aircraftis being encouraged. It is intended that the highspeed traffic should be collected on the autobahn. The ordinary roads not built for the present dense heavy and rapid traffic would be saved from the necessity of constant repairs and efforts would be made to improve them. The super highway will enable the motorist to speed up to at least 90 miles per hour. A lorry driver will be able to travel between two distant cities twice a week instead of making only one return trip. The deterioration of 
the lorry and the general transport costs will be considerably reduced. The new roadways will open up many new picturesque places which will attract foreign visitors. According to the law of June 27, 1933 , the German State railways have been authorised to create a subsidiary company to build and manage an efficient network of super highways as a monopoly.

\section{Ceralumin}

Messrs. J. Stone and Co., Ltd., of Deptford, have introduced a new light alloy to which they have given the name of "Ceralumin C". This alloy contains copper $2 \cdot 5$, nickel $1 \cdot 5$, magnesium $0 \cdot 8$, iron $1 \cdot 2$, silicon $1 \cdot 2$ and cerium $0 \cdot 15$ per cent. It thus belongs to a well-known class of light alloys, but contains eerium in addition to the more usual elements. It is claimed that cerium refines the microstructure, and also suppresses the formation of the brittle ironaluminium constituent. The alloy is used in the heat-treated condition, being heated to $515^{\circ}-535^{\circ} \mathrm{C}$. for four to six hours in order to bring the constituents into solid solution, and then quenched. Ageing is effected in 16 hours at $175^{\circ}$, after which the alloy is again quenched. Chill castings after heat treatment have a tensile strength of 23-27 tons/in. ${ }^{2}$, a proof stress of 21-24 tons/in. ${ }^{2}$, an elongation of 1 per cent, and a Brinell hardness of 130-140. A fatigue range at 20 million reversals of $\pm 8 \cdot 25$ tons/in. ${ }^{2}$ has been obtained, which is high for alloys of this class. When the ageing at $175^{\circ}$ is replaced by ageing at room temperature for five days, the tensile strength is lowered, but an elongation of 4-6 per cent has been obtained. This modified alloy is called "Ceralumin D". Sand castings give rather lower figures. The new alloy is claimed to give smooth castings, and to be suitable for many kinds of aeronautical and automobile purposes.

\section{A 'Perfect' Musical Scale}

IN Chap. viii of his forthcoming work on "Some Questions of Musical Theory" ("From Seven to Seventeen". Pp. 137-166. Cambridge : W. Heffer and Sons, Ltd., 1934. 2s. 6d. net), Dr. W. Perrett divides the octave into 171 intervals which he calls 'hepts'. One sixth of a hept is the least difference of pitch which can be detected by a trained ear and Dr. Perrett shows that if the eleventh, thirteenth and nineteenth harmonics can be dispensed with, 50 of the intervals best known in music can be represented by integral numbers of hepts with errors of less than one seventh of a hept. Thus the fifth is 100, the fourth 71, the major third 55, the minor third 45 . With an instrument constructed on these lines, modulation into any key would be possible, but if it were played by hand four players would be necessary. As an instrument with Bosanquet's 84 keys per octave was constructed at a moderate price half a century ago, the author considers that one with 171 is quite within the bounds of possibility at the present time.

\section{Land Utilisation Survey}

THE third annual report of this survey of Great Britain shows a growing rate of progress towards the completion of the work. With a total of 15,000 finished six-inch sheets, three-quarters of the field work has now been accomplished. Thirty-six counties are completed and twenty-five more are nearly complete. Parts of Norfolk, West Suffolk, the West Riding, Westmoreland, Cornwall, Carmarthen and Somerset still call for more workers. In southern Scotland there are large areas still to be done. A year ago two sheets, reduced to a oneinch scale from the six-inch sheets, were published by the Ordnance Survey. Eight sheets in all have now been published and four more are in the press. Work is proceeding on the reduction and preparation for press of twenty-nine further sheets. It is proposed to publish a series of explanatory memoirs on certain of the sheets and several of these are now in preparation. The report summarises the extent of work done in each county and contains a map of Great Britain showing completed areas.

\section{The Imperial Institute}

The annual report of the Imperial Institute contains the last report of the retiring director of the Institute, Lieut.-Gen. Sir William Furse, to the Board of Governors. Sir William there affirms his belief that the threefold activities of the Institute(1) intelligence, (2) investigations and (3) education -are of immense importance and essential to the economic development of the Empire. He adds that the Imperial Institute is still not sufficiently known and is left overmuch to carry on as best it can. It has never been financed adequately, but from time to time an outside Committee is appointed to investigate the Institute, usually when bankruptcy appears to be impending. Its own resources, from its original endowment and from the letting of rooms, amount to less than $£ 10,000$ per annum: Sir William estimates that it requires an income four to five times this figure. He points out that the Institute has only been kept alive for the past ten years by the munificence of private donors and adds: "In no spirit of ingratitude to these gentlemen, I venture to suggest that this method of carrying on our essential Imperial service is unworthy of our great Empire."

\section{The Cooling of Boulder Dam}

The Boulder Dam forms a huge concrete plug between the walls of the Black Canyon on the Colorado river. According to Science Service of Washington, D.C., it weighs six million five hundred thousand tons. As this concrete sets, the slow chemical reaction that takes place gives off heat. Researches by the U.S. Bureau of Reclamation have shown that in the Boulder Dam sufficient heat would be generated to melt a cube of ice as high as a 24-story building. If no means were adopted to keep cool this great block much damage might be done, as during the protracted cooling and shrinking period there would be a serious risk of dangerous cracks occurring. To obviate this risk, as each section of the concrete is poured it is riddled with coils of pipe. About 560 miles of tubing will be used, and this will be kept in place permanently as the cement hardens. 